\title{
AUTHORING TOOL FOR THE CREATION OF LEARNING OBJECTS IN OCCUPATIONAL EDUCATION TO SUPPORT PEOPLE WITH COGNITIVE DISABILITIES
}

Paola Marisol Pachacama Espín pmpachacama@espe.edu.ec

Rosa Graciela Guerrero Idrovo rgguerrero@espe.edu.ec

29 de marzo de 2021

https://link.springer.com/chapter/10.1007/978-3-030-72654-6 19

\section{RESUMEN}

La tecnología de asistencia se centra en el apoyo a la restauración o de las funcionalidades de las personas con discapacidad, logrando así una mejor calidad de vida y un rendimiento óptimo en las actividades educativas, laborales y actividades sociales. Esta investigación aborda el tema de la educación laboral para personas con discapacidades cognitivas dentro de las Instituciones de Educación Especializada y en el hogar, así como las limitaciones que tienen los tutores para manejar el contenido de aplicaciones tecnológicas porque la mayoría de ellas están diseñadas para una actividad y no permiten al tutor adaptarlo de forma personalizada en función de las necesidades de las personas con discapacidades cognitivas. Se propuso el desarrollo y evaluación de una herramienta de autor denominada "TK-System", que permite a los tutores gestionar objetos de aprendizaje a través de una aplicación web para que puedan ser utilizados por personas con discapacidades cognitivas a través de una aplicación móvil. Para la ejecución de las pruebas de usabilidad y los cuestionarios se consideró a los usuarios en función de sus conocimientos (atención a personas con discapacidades cognitivas e informática), los resultados permitieron determinar que la herramienta es útil y fácil de usar para la creación de objetos de aprendizaje, además de obtener recomendaciones de mejora.

\section{Palabras claves:}

- DISCAPACIDAD COGNITIVA

- TECNOLOGÍA ASISTIVA

- OBJETOS DE APRENDIZAJE

- HERRAMIENTA DE AUTOR

- EDUCACIÓN ESPECIAL 


\title{
AUTHORING TOOL FOR THE CREATION OF LEARNING OBJECTS IN OCCUPATIONAL EDUCATION TO SUPPORT PEOPLE WITH COGNITIVE DISABILITIES
}

\author{
Paola Marisol Pachacama Espín pmpachacama@espe.edu.ec \\ Rosa Graciela Guerrero Idrovo rgguerrero@espe.edu.ec \\ 29 de marzo de 2021
}

https://link.springer.com/chapter/10.1007/978-3-030-72654-6 19

\begin{abstract}
Assistive technology is focused on supporting the restoration or improvement of functionalities of people with disabilities, thus achieving a better quality of life and optimal performance in educational, employment and social activities. This research addresses the issue of employment education for people with cognitive disabilities within Specialized Education Institutions and at home, as well as the limitations that tutors have in managing the content of technological applications because most of them are designed for a specific activity and do not allow the tutor to adapt it in a personalized way based on the needs of people with cognitive disabilities. It was proposed the development and evaluation of an author's tool called "TK-System", which allows tutors to manage learning objects through a web application so that they can be used by people with cognitive disabilities through a mobile application. For the execution of usability tests and questionnaires users were considered based on their knowledge (care of people with cognitive disabilities and IT), the results allowed to determine that the tool is useful and easy to use for the creation of learning objects, in addition to obtaining recommendations for improvement.
\end{abstract}

KEYWORDS:

- COGNITIVE DISABILITIES

- ASSISTIVE TECHNOLOGY

- LEARNING OBJECTS

- AUTHOR TOOL

- SPECIAL EDUCATION 